\title{
COVID-19 IS DEADLY! LONG LIVE THE KING, CORPORATE CASH HOLDINGS!
}

\author{
Akanksha Saxena', R. Ranajee ${ }^{*}$, Ms Saumita Roy ${ }^{1}$ \\ 1. ICFAI Business School, Hyderabad, India \\ * Corresponding Author: Ranajee Ranajee, Associate Professor, ICFAI Business School, Hyderabad, \\ India, $\square$ Email: ranajee@ibsindia.org
}

\begin{abstract}
COVID-19 has adversely affected the human race. With the human race confined to their houses, the level of consumption has gone down and it has a significant negative impact on the cash flows of the existing businesses. In this study, using different scenarios and stress levels, we try to predict the impact of COVID-19 on a business's cash flows and establish the role of corporate cash holdings in avoiding the illiquidity of businesses.
\end{abstract}

Keywords: COVID-19, Illiquidity, Cash crunch, Stress test, Debt structure

\section{Introduction}

Corporate cash holding is a tradeoff between liquidity and investment. Cash is the basis of the sustenance of a business. Excess cash provides liquidity in times of external externalities. It also eliminates the underinvestment problem. The lower level of cash leads to costly external financing for the investment (Habib and Hasan, 2017; Al-dhamari et al., 2015). Holding cash is connected to efficiency gains where businesses with valuable investment ventures and businesses with greater cash flow risks are expected to hold more cash. Holding cash offers liquidity with the flexibility to the businesses (Keynes, 1934), however, it is also regarded as pervasive in nature (Kalcheva and Lins, 2007; Pinkowitz et al., 2012). Researchers have empirically tested and validated the commonly held intentions of firm cash holdings (Baumol, 1952; Mulligan, 1997; Opler et al., 1999; Harford, 1999), its diverse determinants (Ferriera and Vilela, 2004; Chen and Chuang, 2009; Duchin, 2010; Al-Najjar, 2013), and reported an increasing trend in corporate cash holdings.

Irrelevance theory (Keynes, 1934), asserts that investment and financing are distinct decisions and are not affected by each other. So, in a perfect market situation, corporate cash holding should not matter. On the contrary, pecking order theory (Myers and Majluf, 1984) postulates a sequencing in the financing of the projects. The internally generated cash is followed by debt and finally equity. Financing in pecking order theory follows the cost of financing from lowest to highest. Investments by the company and its growth are limited by internal sources of funding during the credit crunch. Small companies have more information asymmetry about their growth assets, and they are financially inadequate. The role of corporate cash holdings becomes important during the time of credit crunch or to such companies (Denis and Sibilkov, 2009). Bates et al., 2009 report the significance of cash holdings, during the economic crisis. External capital market or bank funding becomes challenging during the financial crisis due to the deficit of confidence. Usable cash holding becomes a defence against external instability in the macroeconomic climate.

Based on the above arguments and pieces of evidence, it is important, for investors, to monitor the cash available to a company, its capital expenditure, and its cash flow levels before making an investment decision. Cash use analysis tells investors till what time a business 
is self-sustaining. Investors also need to pay attention to the cash burn rate of a company. Cash burn rate refers to the rate at which businesses absorb the money supply over time. A high-burn business will find itself scurrying for cash from banks or creditors. In order to minimize the cash burn rate and avoid the fate of running out of cash, the businesses should either reduce costs or induce lay-off and pay cuts for workers. When investor enthusiasm is high, non-profitable businesses can finance cash burns through the issuance of new equity securities. Executives must take advantage of attractive loan cycles and affordable interest rates to improve the company's cash position.

Businesses worldwide are facing an economic downturn and unprecedented challenges for survival due to COVID 19. For firms in such challenging times, foreseeing any possible issues for survival is not easy. However, to prepare for future hassle is the need of the hour. A prolonged crisis in the market is very likely to impact the liquidity of firms and during such times, the banks may lead as lenders of first resort (Li et al., 2020; Acharya and Steffen, 2020). Ever since the pandemic has started, finance research has begun to examine the economic impact of COVID-19 (Ramelli and Wagner, 2020; Zhang et al., 2020; Goodell 2020; Baker et al., 2020).

Emerging economies are characterized by a higher level of information asymmetry and a higher level of conflict of interest, between promoter managers and shareholders, due to agency problems (Manos et al., 2007; Kota and Tomar, 2010). This results in the exorbitant cost of external finance in emerging economies when financial resources are not available (Myers, 1977; Myers and Majluf, 1984). So, corporate cash holdings become of utmost importance in emerging markets and bolster the corporate position during difficult external environmental calamities. The emergence of COVID-19 is such an external environmental calamity. The current literature is curiously silent on the role of corporate cash holding as a savior during the external shock. This study is motivated to continue the trail of the economic significance of the external shock. The study finds suitable solutions for the liquidity crunch created by the drop in sales due to COVID-19. Thus, the objectives of the study are to find the impact of COVID-19 on the cash flows of the firm and to identify, determine and report the saviors of the businesses in the stressed external financing environment.

The study finds the answers to the questions such as: What happens to corporate cash holdings during an external shock in the market? How do corporate cash holdings help stressed firms? For how long do the available corporate cash holdings last? What is the role of the financial system, when the availability of credit in the financial system dries considerably? Does the borrowing pattern of firms change after the external shock? Can relying on a greater number of debt sources (Debt heterogeneity) help the firms?

The study is unique and has become prominent during the difficult times of COVID-19. Various reasons hold importance for such a study. COVID-19 has caused exceptional and unprecedented economic consequences all over the world. One such consequence experienced by the firms is the loss of sales and the resulting cash crunch. Examination of such impact will add to the research on the various impacts of COVID-19 on firms' financing. Further, external situations such as COVID-19 impact different firms differently. Thus, in this study, we examine the impact of three levels of reduced sales scenarios on the firm's cash positions. Our second objective is to examine the role of existing corporate cash holdings on illiquidity. The examination entails economic significance for firms as it will help firms to avoid illiquidity and keep the businesses afloat. Finally, the role of different sources of debt available to the firms in avoiding illiquidity should be explored. 
Figure 1: The updated world map of the SARS-CoV-2 coronavirus outbreak shows countries with several confirmed COVID-19 cases (as of 17 April 2020).

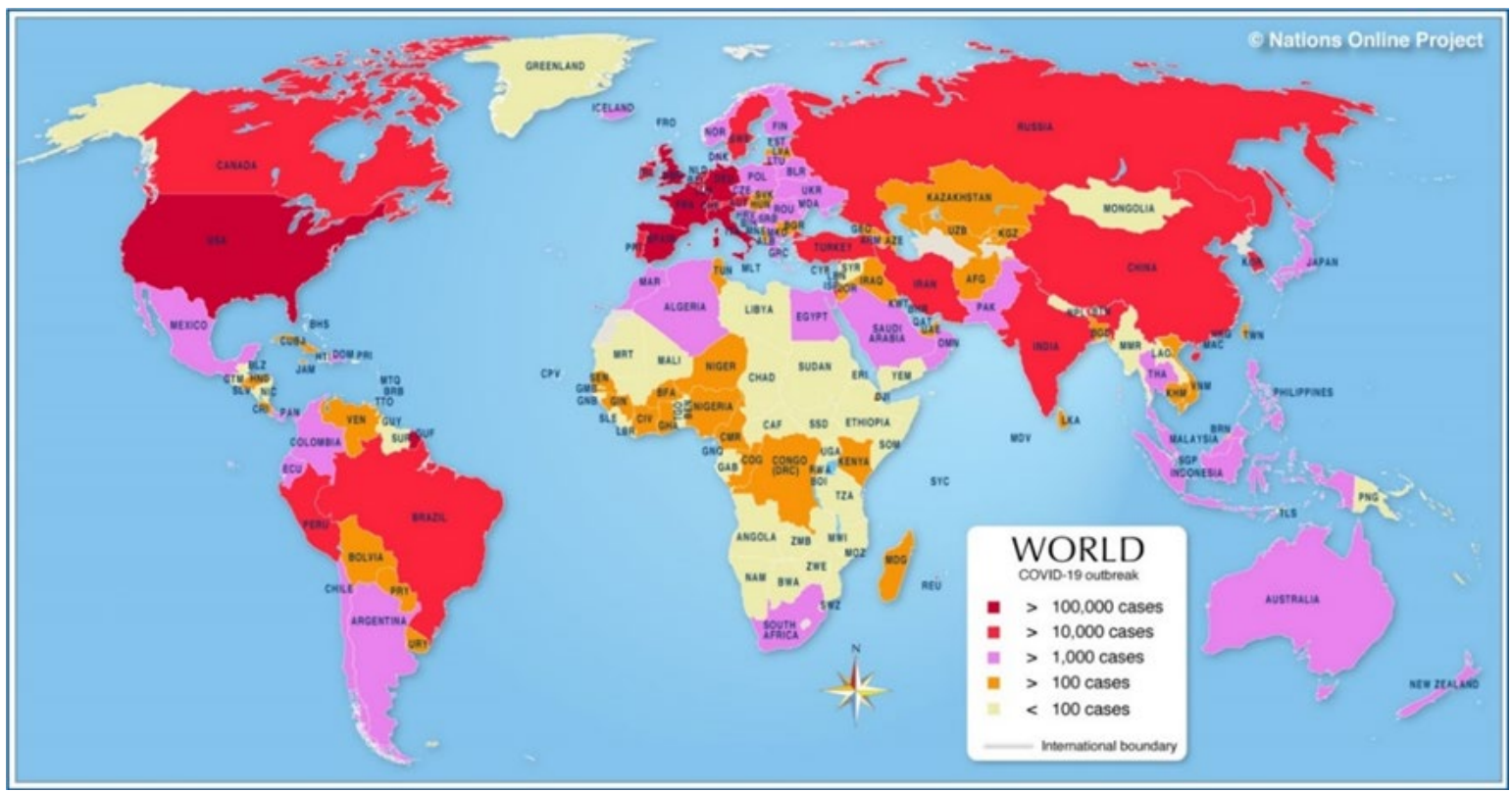

For this study, we have used data for 2127 Indian-listed firms. sensitivity analysis on different scenarios of decrease in sales of $25 \%, 50 \%$, and $75 \%$, is done. The impact of the decrease in sales on operating cash flows and resultant illiquidity is examined in detail. The study establishes the role of corporate cash holdings as the savior of the business against the external calamity of COVID-19. We measure the impact on cash flows with the help of Cash burn rate (CBR). Cash burn rate measures how quickly the firm spends the money. As we start bringing the risky scenarios, we observe the decreasing CBR. As expected, the CBR ratio further shrinks as we intensify the stress rate by applying partial operating flexibility instead of full operating flexibility. Both the ratios: operating cash flow to current liabilities (CFCL) ratio and operating cash flow to total debt (CFTD) ratio show a consistent decrease with an increase in the induced stress on the sales. To prevent the cash crunch, the businesses either burn the existing corporate cash holdings or the businesses would have to increase their current and total liabilities.

Logistic regression results suggest that the corporate cash holdings act as a savior and it accounts for the decrease in the probability of the businesses getting illiquid. The likelihood of firms being illiquid significantly decreases with higher cash holdings in the firm. Leverage, gross margin, ROA, and size also have a similar effect on a decrease in the probability of firms becoming illiquid. For further clarifications on the role of leverage as a savior of businesses, the final section reports the change in debt sources used by firms after the start of the COVID19 pandemic. Overall, the study has implications for companies, managers, and policymakers as well.

\section{Empirical Design and Variable Description}

The primary objective of our study is to investigate the operating cash-flow and liquidity conditions of the Indian firms due to the outbreak of the COVID-19 pandemic. This section of the paper outlines the applied methodology along with the rationale of the procedures used 
to empirically examine our objective. The empirical design is a multi-step approach and is divided into three broad sections. Section 2.1 outlines the framework of the study along with rationale which further enables us to estimate the changes in the cash flow due to reduction in the sales, section 2.2 describes the variable construction for the three liquidity ratios used to access the cash-flow position of the firm, and finally, section 2.3 elaborates methodology to investigate the impact of Covid-19 on the operating cash-flow and liquidity position of the Indian firms.

\subsection{Framework and Rationale Building}

In the first step, we describe theoretically the sensitivity of cash-flow of a firm towards the contraction in the sales or demand. The idea is to test how operating cash flow changes with changes in sales. We estimate the changes in the cash flow empirically as mentioned below (refer, Vito and Gomez, 2020) to estimate the changes in the cash flow empirically and the same is mentioned below.

$$
\partial C F O=\frac{\text { dSales }}{\text { Sales }} \times\left(\left(\text { Sales }-O p . \text { Costs } \times E_{\text {Op.Costs }}\right) \times(1-T R)-\Delta C A \times E_{\triangle C A}+\Delta C L \times E_{\triangle C L}\right)
$$

Where, $\partial C F O$ is the change in the operating cash-flow, $\frac{\text { sales }}{\text { Sales }}$ is the percentage change in the sales of the firm, Op. Costs is the operating cost, TR denotes the corporate tax rate for India, $\triangle C A$ and $\triangle C L$ measure the annual change in the current asset and current liability of a firm respectively, $E_{O p . ~ c o s t s}, E_{\triangle C L}, E_{\triangle C A}$ are elasticities of operating costs, change in current liabilities, and change in current assets as compared to change in sales respectively. in other words, similar to any elasticity measure, these terms estimate the percentage change in the different variables (i.e., operating cost, change in current liability, and change in current asset) due to unit percentage change in the sales for the firm. The elasticity measures are important factors in the model, as they reflect the firm's operating flexibility to combat the adverse external shock impacting the sales of the firm. In the absence of the elasticity terms in the model, a condition where a firm's operating cost, current liability, and current asset are independent of its sales, the demand reduction in the market would impact the change in operating cashflow even more adversely. In that case, $\partial C F O$ would be estimated by multiplying $\partial$ Sales with (1-TR) '. However, in a practical scenario, reduction in sales decreases the operating cost and the working capital which in turn helps offset the adverse impact of the reduction in cash flow partially. Further, we estimate the change in current liability due to the reduction in the sales in similar lines with equation (1) (refer, Vito and Gomez, 2020).

$$
\partial C L=\frac{\partial \text { Sales }}{\text { Sales }} \times C L \times E_{C L}
$$

Where $\partial C L$ is the change in the current liability and $E_{C L}$ is the elasticity of current liability which

\footnotetext{
${ }^{1}$ If we replace $E_{O p .}$ costs $, E_{\triangle C L}, E_{\triangle C A}$ with zero in equation 1, then $\partial C F O$ can be represented as:

$\partial C F O=\partial$ Sales $\times(1-T R)$
} 
measures the percentage change in current liability with one percentage change in sales. Both the measures of $\partial C F O$ and $\partial C L$ will be used to calculate the financial ratios to access the liquidity condition of the firm under the adverse impact of COVID-19. These four elasticities used in Equations 1 and 2 are estimated using the below-mentioned regression model.

$$
\ln \left(y_{i j t}\right)=\alpha_{y}+\beta_{y} \ln \text { sales }_{i j t}+\mu_{j}+\mu_{t}+\varepsilon_{i j t}
$$

Where, $y_{i j t}$ alternatively takes, operating costs, change in current assets, change in current liabilities, and current liabilities for the $i^{\text {th }}$ firm in the $j^{\text {th }}$ industry and year $t . \beta_{y}$ thus represents the elasticities of operating costs $\left(E_{O p .}\right.$ costs $)$, change in current assets $\left(E_{\triangle C_{A}}\right)$, change in current liabilities $\left(E_{\Delta C L}\right)$, and current liabilities $\left(E_{C L}\right) . \mu_{j}$ and $\mu_{t}$ are the industry fixed effect and the year fixed effect respectively. Once the elasticities are estimated using equation 3 , they will be pushed back to the equation 1 and 2 to calculate the values of $\partial C F O$ and $\partial C L$.

\subsection{Variable Construction}

With the theoretical understanding of the impact of contacting sales on both operating cashflow and current liability, in the second step we first, put forward three financial ratios and emphasis their usage to determine the liquidity position of the firm. Next, we link $\partial C F O$ and $\partial C L$ to these financial ratios to understand the impact of the reduction in sales on these financial ratios. The three ratios measuring the liquidity conditions of the firm are: 1) cash burn out ratio, 2) operating cash-flow to current liability ratio, and 3) operating cash-flow to total debt ratio. The cash burn-out ratio (CS /CFO) ${ }^{2}$ measures the period for which a firm can fund its operating cost instead of relying on further cash inflow from creditors or shareholders. The second ratio, Operating cash-flow to current liability (CFCL) reflects the short-term liquidity position of the firm and measures the firm's operating cash-flow position as compared with its current liability $(C L)$. Similarly, the third ratio, operating cash-flow to total liabilities (CFTD) estimates the percentage of operating cash-flow with respect to the total liabilities (TD), describing the extent up to which a firm can pay off all its debts depending upon its operating cash flow. With the operational understanding of the ratios used in the study, we adjust these ratios to $\partial C F O$ and $\partial C L$ which will enable us to interpret the impact of the reduction in sales due to the impact of COVID-19. The mathematical expressions of the adjusted ratios are mentioned below.

$$
\text { Cash Brun Out Ratio }=C B R=\frac{C S}{C F O+\partial C F O}
$$

$$
\text { Operating Cash flow to Current Liability Ratio }=C F C L=\frac{C F O+\partial C F O}{C L+\partial C L}
$$

$$
\text { Operating Cash flow to Total Debt }=C F T D=\frac{C F O+\partial C F O}{T D}
$$

$2 \mathrm{CS}$ is the cash position of a firm. It is the combinations of the cash holding and account receivables of the firm. 
Where CS is the cash position which is calculated as the sum of cash holdings and account receivable, TD is the total debt which is the summation of short-term and long-term debt, $C L$ is the current liability, CFO is the operating cash flow. $\partial C F O$ and $\partial C L$ are as explained in Equations 1 and 2 .

\subsection{Methodology}

In this section, we describe the empirical methodology specifically used for our study. To determine the impact of the reduction in sales on the cash-flow and liquidity position in the Indian firms, we apply a stress test on the liquidity ratios. We examine the sensitivity analysis into four scenarios (one base case and three simulated conditions): base or best-case scenario (i.e., no change in sales), low-risk scenario (sales decrease by $25 \%$ ) moderate-risk scenario (sales decrease by $50 \%$ ); and high-risk scenario (sales decrease by $75 \%$ ).

We first estimate the cash flow from operations (CFO) for the year 2019 (to capture the impact of the COVID-19 outbreak). Next, we estimate sales sensitivity on cash flows ( $\partial C F O)$, i.e., if sales decrease by $25 \%, 50 \%$, and $75 \%$, what impact it has on operating cash flows. To calculate the elasticities used in the calculation of $\partial C F O$ we perform the panel data regression following equation 3 considering 5 years from March 2014 to March 2019. Post calculation of $\partial C F O$ and $\partial C L$ we estimate the three liquidity ratios (CBR, CFCL, and CFTD) following equations 4 to 6 for all four scenarios: base case scenario, low-risk scenario, moderate risk scenario, and high-risk scenario. This will help us gather the liquidity status of firms for the short and long term.

Further, we apply stress tests on the scenarios and take into consideration the partial operating flexibility of the firm rather than full operating flexibility. Full operational flexibility is available to a firm when it can act quickly to protect the firm from the adverse impact of external shock i.e., the outbreak of COVID-19 by reducing its productivity. On the other hand, the firms which cannot adjust their operations quickly in the hour of need and face friction are assumed to be operating in partial flexibility. To examine the partial operating flexibility, the elasticities of operating costs, change in current assets, change in current liabilities, and liabilities are made half $\left(\frac{1}{2} E l_{O p . \text { costs }}, \frac{1}{2} E_{C L}, \frac{1}{2} E l_{\triangle C L}, \& \frac{1}{2} E l_{\triangle C A}\right)$ and put into equations 1 and 2 to estimate the change in operating cash flow and current liabilities and further the three liquidity ratios following Schivardi and Gudio (2020) and Vito and Gomez (2020).

As a part of our empirical analysis, we undertake a logistic regression analysis to identify the probability of a firm being illiquid (categories using CBR ratio). We indicate firms being illiquid if the cash burn ratio (CBR) of the firm is less than zero under high risk and partial operating flexibility scenario. We perform the analysis (result reported in Table 6) by regressing an indicator variable, taking a value of 1 when the firm is illiquid and 0 otherwise on firm characteristics such as cash holdings, gross margin, leverage, size, and return on asset (ROA). The model for the regression is as follows.

$$
\operatorname{Logit}(p)=\alpha_{i}+\beta_{1} \text { cash holding }_{i}+\beta_{2} \text { leverage }_{i}+\beta_{3} \text { Gross margin }_{i}+\beta_{4} \text { size }_{i}+\beta_{5} \text { ROA }_{i}+\varepsilon_{i}
$$

Where, $\log i t(p)=\ln \frac{p}{1-p}$

Further, we investigate the impact of cash crunch or illiquidity on the debt structure of the firms. The pre and post COVID-19 era difference in the debt structure and sources of the nonfinancial Indian firms reveal the probable solutions to combat the cash crunch or adverse impact of reduced demand owing to a decrease in the operating cash flow of the firm. We summarise the operational definition of all the variables used in the study and present it in table 1 below. 
Table 1: Operational definition of the variables used in the study

\begin{tabular}{l|l}
\hline Variable & $\begin{array}{l}\text { Measure/Definition } \\
\text { CFO=Funds from operations - Change in current assets + } \\
\text { Change in current liabilities } \\
\text { Funds from operations=Sales - Operating costs - Depreciation } \\
- \text { Interest expense - Current taxes + Depreciation + Deferred } \\
\text { Taxes } \\
\text { Cash and cash equivalents relative to cash flow from } \\
\text { operations } \\
\text { Cash flow from operations relative to current liabilities }\end{array}$ \\
$\begin{array}{l}\text { Cash Burn Rate (CBR) } \\
\text { Liability Ratio (CFCL) } \\
\text { Cashflow to Total Debt } \\
\text { Ratio (CFTD) } \\
\text { Leverage } \\
\text { Cash holding }\end{array}$ & $\begin{array}{l}\text { Cash flow from operations relative to total debt } \\
\text { Total borrowings relative to total assets } \\
\text { Cash and cash equivalents scaled by total assets }\end{array}$ \\
Gize margin & $\begin{array}{l}\text { (Sales-Cost of goods sold)/sales } \\
\text { In(total assets) } \\
\text { ROA }\end{array}$
\end{tabular}

Note: The table reports the operational definition of the variables used in the study

\section{Data}

To examine the impact of the COVID-19 outbreak on operating cash-flow positions of the Indian firms, we use firm-level data for Indian listed firms from the CMIE Prowess IQ data source. We begin by selecting all listed firms as of March 2019. The total number of firms is 3945 . We further remove the firms having missing values of data of our concern, so that we have data of all the key variables for all the firms. This leaves us with 2127 firms. We begin by applying sensitivity analysis on different scenarios of changes in sales. We first estimate the cash flow from operations (CFO) for the year 2019. Next, we estimate sales sensitivity on cash flows, i.e., if sales decrease by $25 \%, 50 \%$, and $75 \%$, what impact it has on operating cash flows. The elasticity measures $\left(E l_{O p . \text { costs }}, E_{C L}, E l_{\triangle C L}, \& E l_{\triangle C A}\right)$ are estimated following equation 3 from the panel data regression model for 2014 to 2019 i.e., considering 5 years of financial data of the selected firm. The firm characteristics (cash holdings, gross margin, leverage, size, and return on asset) of the firms are also calculated for the selected firms and the descriptive statistics for the variables are summarised in Table 2.

Descriptive statistics of the key characteristic variables reveal that on average the sample firms have $3.7 \%$ of cash holdings to their total asset with a standard deviation of $7 \%$. The mean (median) value of leverage is $33.4 \%(24.9 \%)$ for the sample firm. The higher level of leverage as compared to the cash holdings suggests greater use of leverage than internal capital for financing the investment projects. This also indicates the deviation from the celebrated pecking order theory (Myers and Majluf, 1984), as firms are relying more on debt capital rather than internal funds. The mean (median) gross margin and ROA of our sample are $15.1 \%(9.8 \%)$ and $6.2 \%(6.9 \%)$ respectively. The average size of the sample is 7.9 , while the mean operating cash flow to their total asset is $6.5 \%$ with a standard deviation of $15.5 \%$. The descriptive statistics of gross margin, ROA, and size reflect the average key characteristics of Indian-listed firms. We observe that the value of ROA (0.062) is almost equivalent to the value of CFO (0.065). This indicates that the return on assets is determined by cash flows from operations. Cash flows 
from financing and investment activities do not contribute to the return on assets for the selected sample of firms.

Table 2: Descriptive statistics of characteristics variables of the firms

\begin{tabular}{lcccccc}
\hline Variables & N & Mean & Std. Dev. & P25 & Median & P75 \\
\hline Cash holdings & 2127 & 0.037 & 0.070 & 0.003 & 0.012 & 0.039 \\
leverage & 2127 & 0.334 & 0.385 & 0.117 & 0.249 & 0.415 \\
Gross margin & 2127 & 0.151 & 0.390 & 0.098 & 0.183 & 0.290 \\
ROA & 2127 & 0.062 & 0.109 & 0.025 & 0.069 & 0.113 \\
Size & 2127 & 7.936 & 2.022 & 6.433 & 7.737 & 9.359 \\
CFO(Computed) & 2127 & 0.065 & 0.155 & 0.007 & 0.072 & 0.134 \\
\hline
\end{tabular}

Note: The table represents the summary statistics i.e., number of the firms (N), mean (Mean), standard deviation (Std.Dev.), first quartile (P25), median (Median), and third quartile (P75) of the firm characteristics used in the study for the period of March 2014 to March 2019. Cash holdings are cash and cash equivalents scaled by total assets. Leverage is the total borrowings related to cash holdings. Gross margin is (Sales-Cost of goods sold)/sales. ROA is earnings before interest and taxes scaled by total assets. Size is calculated as the natural log of total assets, and CFO is the computed cash flow from operations.

In Table 2, we display the summary statistics for the returns on the industry portfolios as well as our new COVID-19 attention variable. During our sample period, the durables sector witnesses the highest daily average return, approximately $30 \%$, while energy exhibits the worst, with an average of $-23 \%$. Durables and energy are also the most volatile sectors. Shops, consisting of wholesale and retail, along with healthcare, have the lowest standard deviations among all industries. The descriptive statistics for the COVID-19 attention variable are provided in the last row. The COVID-19 attention has a mean of $3.59 \%$ and standard deviation of $23.95 \%$.

Table 2: Descriptive Statistics - Industry Returns

\begin{tabular}{lrrr}
\hline NoDur & Mean & Median & St. dev. \\
Durbl & -0.0036 & 0.0900 & 2.4217 \\
Manuf & 0.3022 & 0.3500 & 3.7583 \\
Enrgy & -0.0286 & 0.0100 & 3.2534 \\
Chems & -0.2331 & -0.3000 & 4.3949 \\
BusEq & 0.0410 & 0.1300 & 2.5460 \\
Telcm & 0.1783 & 0.4800 & 2.8779 \\
Utils & -0.0156 & 0.1600 & 2.4197 \\
Shops & -0.0159 & 0.1300 & 3.0605 \\
HIth & 0.1623 & 0.2500 & 2.2705 \\
Money & 0.0656 & 0.0700 & 2.2893 \\
Other & -0.0702 & -0.0100 & 3.5400 \\
CoviD-19 attention & -0.0103 & 0.2200 & 2.8526 \\
\hline
\end{tabular}

Note: This table presents mean, median, and standard deviation of returns for each industry listed in the first column. The COVID-19 attention variable is provided in the last row. The sample period is 1 January - 31 July 2020. 


\section{Result}

The result section of our study is divided into three sections. The first sub-section reports the result of the stress test or sensitivity analysis of the three ratios simulated for reduced demand scenarios (low-risk, moderate-risk, and high-risk conditions with full and partial operating flexibility). The result of the logistic regression analysis for illiquid firms is reported in the second sub-section. Finally, The third sub-section reports the debt heterogeneity in terms of the debt sources among the Indian firms before and after the COVID-19 outbreak.

\subsection{Stress Tests on Financial Ratio}

Table 3 presents the results of the stress test of three ratios for the best-case scenario i.e., with no change in the sales (panel A) along with three simulated scenarios (panel $B$ to $G$ ). According to panel $B$ of Table 3 , in the best-case scenario, the cash burn out ratio measures how quickly the firm spends the money shows that with no change in sales for an average firm in our sample, the cash holdings account for about two months for a firm (mean CBR in panel A). Moving forward to the stimulated scenarios, we find that the cash holding period reduces from about one and a half months (mean CBR of panel B) to less than a month (mean CBR of panel D) for low-risk scenario to high-risk scenario, respectively in case of full operating flexibility. On the other hand, in the case of partial operating flexibility, CBR becomes negative for all the three risk scenarios revealing that firms will not be able to hold any cash reserves with the reduced sales (mean CBR in panels $E, F$, and $G$ ). The poor cash holdings position with respect to the annual operating cash-flow of an average firm reveals the existing cash crunch in the firms.

Table 3: Stress test result for CBR, CFCL, and CFTD for low-risk, moderate-risk, and high-risk scenarios with full and partial operating flexibility

\begin{tabular}{|c|c|c|c|}
\hline Ratio & $\mathbf{N}$ & Mean & Median \\
\hline CBR & 2127 & 0.16 & 0.041 \\
\hline CFCL & 2127 & 0.507 & 0.498 \\
\hline CFTD & 2127 & 6.34 & 0.641 \\
\hline Illiquid firms & 534 & & \\
\hline
\end{tabular}

\section{Full operating flexibility}

Panel B: Low risk scenario (Sales drop by $25 \%$ )

\begin{tabular}{lccc}
\hline Ratio & $\mathbf{N}$ & Mean & Median \\
\hline CBR & 2127 & 0.134 & 0.037 \\
CFCL & 2127 & 0.364 & 0.319 \\
CFTD & 2127 & 5.794 & 0.584 \\
llliquid firms & 426 & & \\
\hline \multicolumn{2}{l}{ Panel C: Moderate risk scenario (Sales drop by 50\%) } & & \\
\hline Ratio & $\mathbf{N}$ & Mean & Median \\
\hline CBR & 2127 & 0.101 & 0.031 \\
CFCL & 2127 & 0.319 & 0.289 \\
CFTD & 2127 & 4.57 & 0.488 \\
llliquid firms & 446 & & \\
\hline
\end{tabular}


Panel D: High-risk scenario (Sales drop by $75 \%$ )

\begin{tabular}{lccc}
\hline Ratio & N & Mean & Median \\
\hline CBR & 2127 & 0.078 & 0.027 \\
CFCL & 2127 & 0.269 & 0.249 \\
CFTD & 2127 & 3.389 & 0.378 \\
llliquid firms & 476 & & \\
\hline
\end{tabular}

Partial operating flexibility

Panel E: Low risk scenario (Sales drop by $25 \%$ )

\begin{tabular}{lccc}
\hline Ratio & $\mathbf{N}$ & Mean & Median \\
\hline CBR & 2127 & -0.15 & -0.033 \\
CFCL & 2127 & -1.198 & -1.005 \\
CFTD & 2127 & -13.963 & -1.483 \\
Illiquid firms & 213 & & \\
\hline
\end{tabular}

Panel F: Moderate risk scenario (Sales drop by $50 \%$ )

\begin{tabular}{lccc}
\hline Ratio & N & Mean & Median \\
\hline CBR & 2127 & -0.087 & -0.025 \\
CFCL & 2127 & -0.857 & -0.726 \\
CFTD & 2127 & -10.173 & -1.066 \\
Illiquid firms & 236 & & \\
\hline
\end{tabular}

Panel G: High-risk scenario (Sales drop by $75 \%$ )

\begin{tabular}{lccc}
\hline Ratio & N & Mean & Median \\
\hline CBR & 2127 & -0.061 & -0.019 \\
CFCL & 2127 & -0.551 & -0.479 \\
CFTD & 2127 & -6.307 & -0.678 \\
Illiquid firms & 301 & & \\
\hline
\end{tabular}

Note: The tables report the mean and median of CBR (cash burn ratio), CFCL (cash-flow to current liability ratio), and CFTD (cash-flow to total debt ratio) calculated for seven scenarios (Panel A to G). Panel A reports the ratios for the base case with no change in the sales. Panel B to D report the ratios when reduced sales for $20 \%, 50 \%$, and $75 \%$ and considering fully operational flexibility. Similarly, Panels $\mathrm{E}$ to $\mathrm{G}$ reports the ratios when reduced sales for $20 \%, 50 \%$, and $75 \%$ and considering fully operational flexibility. The row termed illiquid firms in each panel report the number of firms whose CBR is less than 0.

Next, we analyze the liquidity situation of a firm in terms of the average operating cash flow to current liabilities (CFCL) ratio. In the base case, on an average firms would be able to cover about $51 \%$ (mean CFCL of panel A) of their current liability through the operating cash-flow generated from sales. When the sales are reduced by $25 \%$ and firms are assumed to have full flexibility, their capability of covering the current liability through the operating cash flow will be reduced to $36 \%$ (mean CFCL of panel B). However, in the high-risk scenario, firms' capacity of covering their current liability will be about $27 \%$ (mean CFCL of panel D). The CFCL ratios in the case of partial operating flexibility can be interpreted in the same way. Similar to CBR, CFCL becomes more problematic when the firms are assumed to run in partial operating flexibility. The CFCL ratios for all three risk scenarios (low, medium, and high) are negative, averaging from about $-119 \%$ to $-55 \%$ (mean CFCL in panel $E, F$, and $G$ ) showing that firms will be incapable to pay off their current liability using the cash flow generated from cash flow under the reduced demand i.e., a spillover effect.

The evidence of spillover from the CFCL ratio is also supported by the stress test result of CFTD. CFTD measures the percentage of operating cash flow corresponding to the total debt of a firm. When the firms are assumed to be operating with partial flexibility the ratio becomes negative for all three risk scenarios (mean CFTD in panels E, F, and G) indicating that the firms would need to borrow more to be able to operate in the reduced demand situations. 
Apart from the three financial ratios, we also report the number of illiquid firms calculated for each scenario separately. The number of illiquid firms is calculated based on the value of the CBR. The firms are termed to be illiquid when the CBR value is less than zero and becomes negative. The number of illiquid firms ranges from 213 to 534 among different scenarios. Overall, the result of stress tests simulated for three risk conditions suggests that to avoid the cash crunch during an external shock to the firms, they need to borrow more to sustain themselves in the market.

\subsection{Characteristics of the Illiquid firms}

Further, we investigate the illiquid firms identified for the extreme case i.e., high-risk scenario operating with partial flexibility in terms of their characteristics such as cash holdings, leverage, gross margin, size, and ROA. The illiquid firms are those whose CBR is less than 0 for the extreme condition (total 301 firms). We perform two types of analysis: 1) univariate analysis where we report the differences between the key characteristics of the firms divided into categories of liquid and illiquid firms in terms of CBR of extreme condition, and 2) logistic regression where the dependent variable is an indicator of whether a firm is illiquid or liquid and the independent variables are the firm characteristics as mentioned earlier (equation 7). Table 4 reports the result of the univariate analysis. It shows that out of 2127 firms in our sample 301 firms are categorized as illiquid in the extreme scenario i.e., at high-risk where the demand is reduced by $75 \%$ and firms are operating in partial flexibility.

Table 4: Differences between liquid and illiquid firms with partial operating flexibility in the high-risk scenario

\begin{tabular}{lcccc}
\hline Variable & Liquid firms & Illiquid firms & Difference & T-stat \\
\hline Cash holding & 0.039 & 0.022 & 0.017 & 4.068 \\
Leverage & 0.332 & 0.35 & -0.018 & -0.77 \\
Gross Margin & 0.146 & -0.978 & 1.124 & 4.692 \\
Size & 7.986 & 7.632 & 0.354 & 2.816 \\
ROA & 0.066 & 0.038 & 0.028 & 4.193 \\
Obs. & 1826 & 301 & & \\
\hline
\end{tabular}

Note: The table presents the differences between liquid and illiquid firms. Column 1 presents the mean values of variables for liquid firms, and column 2 presents the mean values for illiquid firms. Columns 3 and 4 report the difference in the variables and the T-statistics of mean differences between liquid and illiquid firms respectively.

From the difference and the associated T-stat of the key characteristics of the two categories of the firm, it can be commented that the illiquid firms are smaller in size, possess fewer cash holdings, and earn less gross margin and ROA. The leverage level of illiquid firms is higher although the t-stat is not significant for the same. Next, Table 5 reports the result of the logistic regression analysis which reveals the probability of a firm being illiquid depending upon its key characteristics. The result of the logistic regression is the validation of the univariate analysis. We perform two regression models with and without including the industry fixed effect to control for the industry shock which could modify the probability of a firm being illiquid. The first and third columns report the regression coefficients of logit regression without and with industry fixed effects respectively.

The second and fourth columns report the marginal effects of each variable. The results suggest that cash holding accounts for the decrease in the probability of the firms getting illiquid. The likelihood of firms being illiquid significantly decreases with higher cash holdings in the firm. Gross margin, ROA, and size also account for the decrease in the probability of firms becoming illiquid. In terms of economic significance, one standard deviation increase in the cash holdings of a firm leads to a $4.07 \%$ (marginal effect * standard deviation= 58.22* 0.07) decrease in the chance of it becoming illiquid. Similarly, one standard deviation increase in 
gross margin, ROA, and size of a firm leads to a $0.59 \%, 1.52 \%$, and $1.66 \%$ decrease in the chances of it becoming illiquid respectively. The leverage difference between liquid and illiquid firms is not significant. The results are consistent while using the industry effect as well. The key characteristics analysis of the illiquid firm reveals that firms should pay attention to building their cash reserve, and aim to earn higher ROA to combat the cash crunch situations.

Table 5: Result of determinants of illiquidity

\begin{tabular}{|c|c|c|c|c|}
\hline Variable & Illiquidity & Marginal effects & Illiquidity & Marginal effects \\
\hline \multirow[t]{2}{*}{ Cash holding } & $-4.983^{* * *}$ & $-58.22 \%$ & $-4.745^{* * *}$ & $-55.99 \%$ \\
\hline & -1.3 & & -1.281 & \\
\hline \multirow[t]{2}{*}{ Leverage } & -0.078 & $-0.91 \%$ & -0.097 & $-1.14 \%$ \\
\hline & -0.1 & & -0.103 & \\
\hline \multirow[t]{2}{*}{ Gross Margin } & $-0.130^{* *}$ & $-1.52 \%$ & $-0.126^{* *}$ & $-1.49 \%$ \\
\hline & -0.053 & & -0.054 & \\
\hline \multirow[t]{2}{*}{ Size } & $-0.070 * *$ & $-0.82 \%$ & $-0.080 * *$ & $-0.95 \%$ \\
\hline & -0.033 & & -0.033 & \\
\hline \multirow[t]{2}{*}{$\mathrm{ROA}$} & $-1.195^{*}$ & $-13.96 \%$ & $-1.399 * *$ & $-16.51 \%$ \\
\hline & -0.615 & & -0.606 & \\
\hline Industry FE & YES & & NO & \\
\hline \multirow[t]{2}{*}{ Constant } & $-1.230 * * *$ & & $-0.926^{* * *}$ & \\
\hline & -0.286 & & -0.271 & \\
\hline Obs. & 2127 & & 2127 & \\
\hline Pseudo R2 & 0.0418 & & 0.0307 & \\
\hline
\end{tabular}

Note: The table presents the results of the regression for determinants of illiquidity. The dependent variable is the dun with a value of 1 for illiquid firms and 0 for liquid firms. Cash holdings are cash and cash equivalents scaled by total ass Leverage is the total borrowings related to cash holdings. Gross margin is (Sales-Cost of goods sold)/sales. ROA is earn before interest and taxes scaled by total assets. Size is calculated as the natural log of total assets, and CFO is computed cash flow from operations. Standard errors are in parenthesis with, ${ }^{* * *},{ }^{* *}$, and, ${ }^{*} p<0.1$ denote the significa level at $1 \%, 5 \%$, and $10 \%$ levels, respectively.

\subsection{Debt Heterogeneity as saviour during COVID-19}

After observing an insignificant impact of the leverage on the firm's liquidity position, in this section, we further investigate the impact of cash crunch or illiquidity on the debt structure of the firms. We explore the link between the two and suggest a future direction to finance research. We source the debt heterogeneity pattern data of Indian firms from the Prowess IQ database. The database provides us not only the total debt used by the firms but also describes each component in total debt ${ }^{3}$. Each debt source account for different characteristics and thus indicates the quality of the firm ${ }^{4}$, thus examining the debt heterogeneity pattern becomes imperative. We source the debt structure data for pre and post COVID-19. For reference, Feb-20 is considered as the pre-COVID-19 period and April-20 is taken for the post-COVID-19 period (As it was only from March 22, 2020, the Government of India announced the nation-wide lockdown).

3 This definition of debt heterogeneity takes into account of both long term and short-term debt sources and among these sources, the actual source of borrowings is considered.

4 Refer to Rauh and Sufi, 2010 \& Colla et al., 2013 
Table 6: Change in debt structure patterns after COVID-19. Data sourced for 3952 non-financial listed firms as of March 2020 from the CMIE Prowess IQ database

\begin{tabular}{lccc}
\hline Variables & $\begin{array}{c}\text { Feb-20 } \\
\text { In Rs. } \\
\text { (Millions) }\end{array}$ & $\begin{array}{c}\text { Apr-20 } \\
\text { In Rs. (Millions) }\end{array}$ & $\begin{array}{c}\text { (+) Increase or (-) } \\
\text { Decrease }\end{array}$ \\
\hline $\begin{array}{l}\text { Bank borrowings } \\
\text { Financial Institution }\end{array}$ & 4041 & 8825 & 4784 \\
borrowings & 850 & 699 & -151 \\
Government borrowings & 1473 & 1574 & 101 \\
Syndicated borrowings & 20533 & 627 & -19905 \\
Debentures and bonds & 21729 & 36903 & 15174 \\
Foreign currency borrowings & 10268 & 8281 & -1987 \\
Loans from promoters and & & & \\
directors & 75 & 71 & -3 \\
Inter-corporate loans & 756 & 2271 & 1515 \\
Deferred credit & 5490 & 7824 & 2334 \\
Interest accrued and due & 851 & 199 & -652 \\
Hire Purchase loans & 1647 & 2096 & 449 \\
Fixed deposits & 248 & 334 & 86 \\
Commercial Paper & 20264 & 16672 & -3593 \\
Other Borrowings & 1251 & 6772 & 5521 \\
Total borrowings & 5913 & 1916 & -3997 \\
\hline Note Tabo & & & \\
\hline
\end{tabular}

Note: Table reports the change in the uses of types of debt sources in the pre and post COVID-19 period.

We observe a substantial decrease in the total borrowings of the firms, however, the contribution from a few of the debt lenders increased. The maximum increase in the contribution of debt is from the debentures and bonds borrowings. Bank borrowings have increased. The increase in bank borrowings indicates bankers as the lenders of first resort. The increase in inter-corporate loans also indicates an increase in uses of the long-lived king of corporate cash holding in helping not just own businesses but for businesses of related and concerned parties.

\section{Implication and conclusions of the study}

The empirical investigation performed in various stages reveals both current cash-flow or liquidity conditions and future adverse impact on cash flow due to reduction in the demand for the Indian firms. Finally, we summarise the outcomes of the investigation and outline probable solutions to manage the adverse impact of COVID-19 on sales. Stress test results show that due to reduction in sales firms become illiquid and cannot repay their current liabilities using the cash flow from the operations. Further key characteristics analysis of the illiquid firms reveals that smaller firms, having less gross margin, earning lesser ROA are more suspectable to become illiquid in an adverse condition. Finally, pre and post COVID- 19 era debt structure comparison for the Indian firms indicates that diversified loan structure may help the firm overcome the cash crunch situations created due to the adverse shock of the pandemic. Apart from the use of various debt sources, the firms should have access to inexpensive short-term loans granted by the Government or other regulated market sources 
to mitigate the illiquidity conditions. A tax-deferral provision can also be considered as another way to solve the problem.

Retained cash holdings act as the saviour during the difficult times of extremely adverse macroeconomic conditions, one of which is presented to human society with the outbreak of the global pandemic of COVID-19. In a perfect market condition, corporate cash holding should not matter. But in this study, our objective was to check the sensitivity of operating cash flows, by considering, different scenarios of sales drop due to COVID-19. The resultant impact on operating cash flows and illiquidity and role of corporate cash holdings in decreasing the pace of cash burn rate and prolonging the life of the businesses by avoiding illiquidity in the short run or till the time adverse external macroeconomic environment stabilizes. Corporate cash holdings are helpful in avoiding the cash crunch of the businesses and acts as a saviour of business. Thus, justifies our title COVID-19 is deadly! Long Live the King, Corporate Cash Holdings!

\section{References}

Acharya, Viral, and Sascha Steffen. "Stress tests" for banks as liquidity insurers in a time of COVID." VoxEU. org, March 22 (2020).

Al-Dhamari, R., \& Ismail, K. N. I. K. (2015). Cash holdings, political connections, and earnings quality. International Journal of Managerial Finance.

Al-Najjar, B. (2013). The financial determinants of corporate cash holdings: Evidence from some emerging markets. International business review, 22(1), 77-88.

Baker, S. R., Bloom, N., Davis, S. J., \& Terry, S. J. (2020). Covid-induced economic uncertainty (No. w26983). National Bureau of Economic Research.

Bates, T. W., Kahle, K. M., \& Stulz, R. M. (2009). Why do US firms hold so much more cash than they used to?. The journal of finance, $64(5), 1985-2021$.

Baumol, W. J. (1952). The transactions demand for cash: An inventory theoretic approach. The Quarterly Journal of Economics, 545-556.

Chen, Y. R., \& Chuang, W. T. (2009). Alignment or entrenchment? Corporate governance and cash holdings in growing firms. Journal of Business Research, 62(11), 1200-1206.

Colla, P., Ippolito, F., \& Li, K. (2013). Debt specialization. The Journal of Finance, 68(5), $2117-$ 2141.

De Vito, A., \& Gomez, J. P. (2020). Estimating the COVID-19 cash crunch: Global evidence and policy. Journal of Accounting and Public Policy, 106741.

Duchin, R. (2010). Cash holdings and corporate diversification. The Journal of Finance, 65(3), 955-992.

Denis, D. J., \& Sibilkov, V. (2009). Financial constraints, investment, and the value of cash holdings. The Review of Financial Studies, 23(1), 247-269.

Ferreira, M. A., \& Vilela, A. S. (2004). Why do firms hold cash? Evidence from EMU countries. European financial management, 10(2), 295-319. 
Goodell, J. W. (2020). COVID-19 and finance: Agendas for future research. Finance Research Letters, 101512.

Habib, A., \& Hasan, M. M. (2017). Social capital and corporate cash holdings. International Review of Economics \& Finance, 52, 1-20.

Harford, J. (1999). Corporate cash reserves and acquisitions. The Journal of Finance, 54(6), 1969-1997.

Kalcheva, I., \& Lins, K. V. (2007). International evidence on cash holdings and expected managerial agency problems. The review of financial studies, 20(4), 1087-1112.

Keynes, J. M. (1934). The applied theory of money (Vol. 2). Macmillan and Company.

Kota, H. B., \& Tomar, S. (2010). Corporate governance practices in Indian firms. Journal of Management \& Organization, 16(2), 266-279.

Li, L., Strahan, P. E., \& Zhang, S. (2020). Banks as lenders of first resort: Evidence from the Covid19 crisis. The Review of Corporate Finance Studies.

Manos, R., Murinde, V., \& Green, C. J. (2007). Leverage and business groups: Evidence from Indian firms. Journal of Economics and Business, 59(5), 443-465.

Mulligan, C. B. (1997). Scale economies, the value of time, and the demand for money: Longitudinal evidence from firms. Journal of Political Economy, 105(5), 1061-1079.

Myers, S. C. (1977). Determinants of corporate borrowing. Journal of financial economics, 5(2), 147-175.

Myers, S. C., \& Majluf, N. S. (1984). Corporate financing and investment decisions when firms have information that investors do not have (No. w1396). National Bureau of Economic Research.

Opler, T., Pinkowitz, L., Stulz, R., \& Williamson, R. (1999). The determinants and implications of corporate cash holdings. Journal of financial economics, 52(1), 3-46.

Schivardi, F., \& Guido, R. (2020). A simple method to estimate firms' liquidity needs during the Covid-19 crisis with an application to Italy. 